\begin{tabular}{|c|c|c|c|c|c|c|}
\hline \multirow{4}{*}{ Impact Factor: } & ISRA (India) & $=3.117$ & SIS (USA) & $=0.912$ & ICV (Poland) & $=6.630$ \\
\hline & ISI (Dubai, UAE & $=0.829$ & РИНЦ (Russia & $=0.156$ & PIF (India) & $=1.940$ \\
\hline & GIF (Australia) & $=0.564$ & ESJI (KZ) & $=8.716$ & IBI (India) & $=4.260$ \\
\hline & JIF & $=1.500$ & SJIF (Morocco & $=5.667$ & OAJI (USA) & $=0.350$ \\
\hline
\end{tabular}

SOI: $\underline{1.1 / T A S} \quad$ DOI: $10.15863 / T A S$
International Scientific Journal
Theoretical \& Applied Science
$\begin{array}{ll}\text { p-ISSN: } 2308-4944 \text { (print) } \quad \text { e-ISSN: } 2409-0085 \text { (online) } \\ \text { Year: } 2019 \quad \text { Issue: } 02 \quad \text { volume: } 70 \\ \text { Published: } 11.02 .2019 \quad \text { http://T-Science.org }\end{array}$

SECTION 13. Geography. History. Oceanology. Meteorology.
QR - Issue

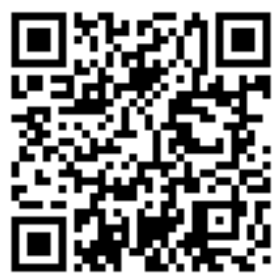

QR - Article

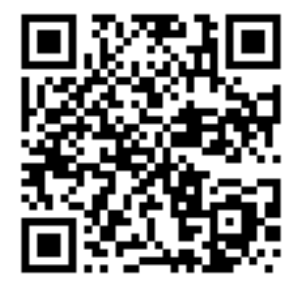

Sh.Sh. Choriev

$\mathrm{PhD}$ the History Faculty of the National University of Uzbekistan, Tashkent, Uzbekistan sherzodch@rambler.ru

\title{
THE HISTORY OF BALTIC NATION DIASPORA IN UZBEKISTAN
}

Abstract: This article highlights the theoretical issues of the history of Baltic Nation Diaspora in Uzbekistan which based on scientific sources, Central State Archive of Uzbekistan and Latvian State Archive.

Key words: Diaspora, Migration, Baltic Nation, WWII, Evacuation, Turkestan Autonomous Soviet Socialist Republic (TASSR), Council of People's Commissars (CPC), Latvian, Lithuanian, Estonian, Uzbekistan, Tashkent.

Language: English

Citation: Choriev, S. S. (2019). The history of Baltic nation diaspora in Uzbekistan. ISJ Theoretical \& Applied Science, 02 (70), 19-25.

Soi: http://s-o-i.org/1.1/TAS-02-70-5 Doi: crossef https://dx.doi.org/10.15863/TAS.2019.02.70.5

\section{Introduction}

Currently, migration processes have become a very topical issue. In historic times, since about 3000 $\mathrm{BC}$, various clearly identifiable groups of people have moved from area to area of the globe. In doing so, they have profoundly influenced on the human history. In prehistory, the movement of a group is usually evident through traces of a shared language, which the migrants bring to a new place. The spread of a cultural influence, such as styles of pottery or religious practices, will show that there was a close link between regions but will not necessarily prove permanent migration.

In the period of the Russian Empire and the Soviet Union due to socio-political processes and for other reasons such as October Revolution, the Second World War, the Soviet Union nations was migrated to other republic territories.

The disintegration of the Soviet Union has been one of the world's important historical events, which has given rise to profound geopolitical changes not only in the former USSR, but also on a global scale. Besides, the collapse of the Soviet Union revealed a number of opportunities in the world community, including in cooperation with the former Soviet republics. Especially today, cooperation between Uzbekistan and the Baltic countries is developing. However, as known on the history that, the history of mutual economic, cultural ties between these countries dates back to several centuries. In the middle ages trade route which crossed via Baltic lands was efficient route for traders who went from
East to North Russian lands. In the result of archeological finds has been founded coins of Samanid Empire from Scandinavian countries, Baltic ambers was recovered from the Pamir zone historical memories which belong to XIII-XIV centuries and from the Baltic lands had been located coins of Khwarazmian dynasty [1, s. 9-10; -s.27-28].

Part 1: Migration of Baltic people to Central Asia from 1860 until WWII

A lot of research has been done on the history of migration of the Baltic peoples. In the study, the migration processes of the Baltic nations throughout Russia are studied in four stages:

The first stage: from 1860 to the Crimean and Samara regions, partially to the Central Asian region.

The second stage: Beginning in 1870, the governments of the Caucasus, Stavropol, Kuban, the central regions of Russia, Siberia and Central Asia.

The third stage includes the territories of the Caucasus, the Black Sea region, the territories of Siberia, Tver and Central Asia from 1884 to 1886.

The fourth stage was moved from 1900 to 1917 to Siberia, Tomsk, Tobolsk and Turkestan[2, s.4547].

As mentioned above representatives of the Baltic people first appeared in Central Asia as part of the Russian troops in the mid-60s of the XIX century. Most of the migrant population lived in Turkestan, partly in the Russian settlements of Bukhara and Khorezm, in the territories surrounding the Russian Empire. The main goal of the Russian 


\begin{tabular}{|c|c|c|c|c|c|c|}
\hline \multirow{4}{*}{ Impact Factor: } & ISRA (India) & $=3.117$ & SIS (USA) & $=0.912$ & ICV (Poland) & $=6.630$ \\
\hline & ISI (Dubai, UAE & $=0.829$ & РИНЦ (Russia) & $=0.156$ & PIF (India) & $=1.940$ \\
\hline & GIF (Australia) & $=0.564$ & ESJI (KZ) & $=5.015$ & IBI (India) & $=4.260$ \\
\hline & JIF & $=1.500$ & SJIF (Morocco) & $=5.667$ & OAJI (USA) & $=0.350$ \\
\hline
\end{tabular}

settlements in these areas was to support the Russian military in the struggle against the local population with armed conflicts, only in 1903-1913, 116 Russian settlements were created in Turkestan [3, s.95-99]. In Russian settlements not only of Russian origin, but also of other European ethnic groups, including Latvian, Lithuanian and Estonian. According to the census of 1897, the Baltic peoples of the country were the lowest in the Turkestan population (Turkestan, Bukhara, Khorezm) and consisted of 287 (168 men, 119 women) [4, ].

Representatives of the Latvian nationality for the first time appeared in Central Asia as a part of the Russian troops in the mid-60s of the XIX century. Later, a small number of Latvians - skilled workers, officials, teachers, doctors, and servants - settled in Turkestan. Most of them were engaged in craft, trade, and belonged to the petty-bourgeois stratum. In 1905, the church Evangelical Lutheran parish as a whole 150 Latvians visited the city of Turkestan. Central Asia has become a haven for of many Latvian revolutionaries who went underground.

WW I marked a new stage in the resettlement of Latvians in the region. By the end of 1915, no less than 1,5 thousand refugees from all historical and cultural regions of Latvia (that time governorates of Courland, Livland and cultural region of Latgale that belongs to the Vitebsk governorate of Russian Empire), later about 600 people re-evacuated from them. The Latvian Society was created on this basis. Already later, in the 20s, the Polish-Latvian National Bureau under the Council of National Minorities was established to regulate the lives of the multi-ethnic population of Turkestan.

At the time of Russian Civil War in Central Asia there were a couple of Latvian Bolsheviks J.Rudzutaks, J.Peterss, A.Auzina, R.Bērziņš, F.Cīrulis, H.Eihe, J.Kiršs, O.Līdaks. It must be commented on the biography of some of them.

Jēkabs Peters was a security officer, a member of the Central Committee of the Turkestan Bureau of the RKP (b), head of the ChK (Emergency Commission) of the Republic. Jānis Rudzutaks. He was born in the province of Courland (Latvia) in the family of a farmhand. Latvian by birth, he was recorded on his birth certificate as "Jahnis Rudsutaks"[5, s.12] . He finished 2 classes at parish school. From 1904, He started working at the tool factory of the Otto Erbe joint-stock company in Riga. In 1906, he was elected as a member of Riga Committee of the RSDLP, in 1907 he headed the Windau organization of the RSDLP and in the same year was arrested. In 1909, he was sentenced by a military court to 10 years of hard labor. He served the punishment in the Riga Central and Butyrskaya prison (Moscow). Only after the February Revolution of 1917, he was released. Later, he became a member of the October battles of 1917 in Moscow. In 19171920 he worked for a lot of responsible organizations. From October 1919, he became a member of the Turkestan Commission of the AllRussian Central Executive Committee and SNK of the RSFSR. In 1920-1921, he was the chairman of the Central Committee of the trade union of transport workers, as well as the chairman of the Turkestan Commission of the All-Russian Central Executive Committee and SNK of the RSFSR. From March to October, in 1921, he was a chairman of the Turkestan Bureau of the Central Committee of the RKP (B.). From 1922, he worked as a chairman of the Central Asian Bureau of the Central Committee of the RCP (B.). Ya. E. Rudzutak was arrested in 1937 and shot in 1938. In 1956, his name was rehabilitated by the Military Collegium of the USSR Supreme Court on January 23, 1956, and in September of the same year, the CPC (Central Political Committee) under the Central Committee of the CPSU was reinstated in the party.

Fritz Yanovich Cirul (Cirulis), (1886-1925 (who later changed his surname to Tsirul)) - was born into a family of Latvian farm laborers in 1886. He received his education at home. For a long time, he lived in Tashkent where in 1904 he joined the Russian Social Democratic Party (Bolsheviks) An active participant in the revolutionary movement, was repeatedly prosecuted, spent a total of 7 years and 2 months in prisons in the Russian Empire, and spent 2 more years and 6 months in exile. After the October Revolution, Cirul actively participated in the establishment of Soviet power on the territory of Central Asia, and from December 1917 headed the Tashkent city guard. In the early 1920s, he led the Tashkent city police, and also headed the department of management of the city executive committee. In November 1922, after transferring to another position of Gregory Alexandrovich Rusanov, Cirul headed the Main Political Directorate (GPU) of Turkestan. Among the Latvians there were many workers in the field of education and medicine. For example, in the Central Asian military Latvian I.Ya. Dos. Also, the Latvians showed their good irrigation skills in cotton growing areas [6, s.95-108].

In the late 60s. XIX century. in the Russian army in Turkestan were and Lithuanians. A little later, Lithuanian-born civilians with Russian citizenship began to arrive here. At the beginning of the last century, the Lithuanians made up a significant share in the petty-bourgeois stratum of Tashkent, Samarkand and the cities of the Fergana Valley. Among those who came from the western national regions of the Russian Empire in Turkestan, there were about 1,000-1,200 Lithuanians.

Since 1902, the main curator of Catholics of the Central Asian region Lithuanian priest Justin Pranaitis is appointed (1861-1917). Thanks to his energy and talent leader in the capital of the Turkestan Governor-General of the capital - a priest's house is being built in Tashkent, temporarily 


\begin{tabular}{|c|c|c|c|c|c|c|}
\hline \multirow{4}{*}{ Impact Factor: } & ISRA (India) & $=3.117$ & SIS (USA) & $=0.912$ & ICV (Poland) & $=6.630$ \\
\hline & ISI (Dubai, UAE & $=0.829$ & РИНЦ (Russiz & $=0.156$ & PIF (India) & $=1.940$ \\
\hline & GIF (Australia) & $=0.564$ & ESJI (KZ) & $=\mathbf{5 . 0 1 5}$ & IBI (India) & $=4.260$ \\
\hline & JIF & $=1.500$ & SJIF (Morocce & $=5.667$ & OAJI (USA) & $=0.350$ \\
\hline
\end{tabular}

replacing prayer house, and a beautiful Roman Catholic church, as well temples in Samarkand and Skobelev From the moment of the arrival of the father of Pranaitis, the mass in the Tashkent Catholic church and other Lithuanian concentration centers during his official business trips were conducted, in addition to Russian, Polish, and in Lithuanian.

Some Lithuanians were Lutherans and attended evangelical Lutheran churches. In 1905, there were 10 Lithuanians in the Tashkent parish Lutheran. Their number significantly increased during the First World War at the expense of prisoners of war and refugees. Most Lithuanians headed to Tashkent, the Syrdarya `and Samarkand regions.

In December 1915, the priest Justin Pranaitis prepared a shelter for refugees from Lithuania. In the dormitory at the "Polish Church" more than 60 people were employed and provided with work. Many of them were able to return home in the spring of 1916. In February 1917, Justin Pranaitis died. The next curator was father Bronislav Ruthenis from Lithuania. In the province Father Rutenis was engaged in religious activities for over twenty years.

In May 1917, the Union of Citizens of Lithuanian nationality was formed in Tashkent. Later it was renamed the National Society "Viltis". Similar national Lithuanian groups are being established in other cities of the region. At the same time, one representative from the Lithuanians of Turkestan was delegated to the Lithuanian Seym convened in Petrograd. The Polish-Lithuanian section was formed among the first at the People's Commissariat for the TurkASSR. With her assistance in 1922, most Lithuanians returned to their historic homeland [7, s.95-149]. Spiritual culture. The Baltic republics are one of the foremost republics of the Soviet Union in terms of cultural development. In the past, the development of national culture was hampered in Estonia and Latvia by the German barons, in Lithuania by Polish landlords. This was also facilitated by confessional disunity. By faith, the population of the Baltic states was divided into Catholics, Lutherans and Orthodox. Catholicism was common in areas that were long under Polish rule, in Lithuania and eastern Latvia among the Latgalians. Lutheranism from the 16th century was forcibly imposed by German pastors among Estonians and western Latvians. Orthodox were residents of the border with the Russian regions. According to ethnographic materials, we can say that Poles and Lithuanians for religious reasons were also in the same way. And the second side of the Polish diaspora was very much in Central Asia ${ }^{1}$. And from the second side, according to statistical data on Turkestan, Lithuanians and Poles were counted

${ }^{1}$ By the second decade of the XX century. in Turkestan (including the Emirate of Bukhara and the Khiva Khanate), there were already 9-10 thousand Poles. together. For example, by statistical according to data, in 1915 there lived Poles and Lithuanians: in Samarkand - 1,866, in Kattakurgan - 15, in Jizzakh 16.

In 1918 in Tashkent was organized Latvian social-democratic group and members of group were more than 40 people [8, s.95-149]. Furthermore, in 1922 Department of little nationality under the Committee in national cases allowed to act Latvian section [9, p. 2]. However, a little later on 14th July 1922 adopted Turkestan Central Executive Committee's decree № 102 about the latish section stopped its actions.

At the turn of the XIX - XX centuries on the lands of present-day Uzbekistan settled and Estonian peasants, but in small quantities. Near Tashkent, in the lower part of the Kugart valley, there were several Estonian families. The list of persons of the Lutheran religion (1886), who lived in the Russian part of Tashkent, included the tradesman of the Estland gubernia Otto Redlin as well as in the Andijan district of Fergana region, three farms, about 30 inhabitants of whom were engaged in farming and animal breeding, and quite successfully. Estonian peasants, in comparison with the situation of peasant migrants of Slavic nationalities, lived many times more prosperously, using the cheap labor of both the indigenous and Russian population.

Estonians took an active part in the activities of the community of Baltic immigrants, zealously observed all religious rituals and traditions of his people.

In 1905, the Evangelical parish as a whole was registered 100 Estonians. Some Estonians professed Orthodoxy. After re-evacuation of World War I refugees in Central Asia there are about 200 Estonians left. According to data sheets of evangelical Lutheran societies, in the 20s. XX century. Estonians lived in Tashkent, Samarkand, Fergana and Kokand. In the late 30s. a small number arrived again in Central Asia Estonians evicted from the border regions of the USSR and Finland [10, s.254].

The Baltic, living in Turkestan, served in the military, postal, telegraph, industrial and other systems of national ownership. In Turkestan, they also developed new technologies. Latvian, Lithuanian engineers also engaged in the manufacture of bicycles, motorcycles and trams. Latvian, Lithuanian engineers also engaged in the manufacture of bicycles, motorcycles and trams. The Swift bike they created is mentioned in press releases that they won the Olympic Games in Riga, Stockholm and Kiev [11, №77].

In the recent past, in the twentieth century, there was a brutal political disaster called the Second World War (1939-1945), the instigator of which was fascist aggression, directing the main forces to conquer the countries of Europe and the Soviet state. 


\begin{tabular}{|c|c|c|c|c|c|c|}
\hline \multirow{4}{*}{ Impact Factor: } & ISRA (India) & $=3.117$ & SIS (USA) & $=0.912$ & ICV (Poland) & $=6.630$ \\
\hline & ISI (Dubai, UAE & $=0.829$ & РИНЦ (Russia) & $=0.156$ & PIF (India) & $=1.940$ \\
\hline & GIF (Australia) & $=0.564$ & ESJI (KZ) & $=5.015$ & IBI (India) & $=4.260$ \\
\hline & JIF & $=1.500$ & SJIF (Morocco) & $=5.667$ & OAJI (USA) & $=0.350$ \\
\hline
\end{tabular}

In the struggle for the liberation of the USSR from the invaders (the Soviet-German War - 1941-1945) all its republics participated, including the region of Central Asia. First, the peoples of the region supplied the army with manpower, food, clothing, ammunition, and material values; secondly, the work of the population in the rear was invested in the cause of victory; thirdly, evacuated people were placed in these territories, as well as objects of the national economy. The study of the above facts at this stage is important to ensure the solidarity and cohesion of the peoples, both of the region itself and of neighboring countries. Great value in the study of this issue are primary sources, in particular, documents stored in the archives of the republics.

Almost from the very beginning of the war, the evacuation of industry, which the German invasion threatened, was one of the main concerns of the Soviet government. In the first days of the war, two large industrial centers were lost: Riga and Minsk. But in Lithuania, in the rest of Latvia, in Belarus and Western Ukraine there were no particularly important industrial enterprises. The most important industrial areas of the European part of the Soviet Union, which were under threat of being captured or destroyed by bomber aircraft, were, firstly, all of Central and Eastern Ukraine, including the districts of Kharkov, Dnepropetrovsk, Krivoy Rog, Nikopol and Mariupol, and the Donbass and, secondly, Moscow and Leningrad industrial centers. Evacuation of industry in the Urals, the Volga region, Western Siberia and Central Asia began at a very early stage of the war[12, s.41_45]. It should be noted that to preserve the lives of people and cope with such huge industrial plants that were evacuated and planned for evacuation required huge workforces and specialists. It can be said that the front will provide products for the gable seats were the source of the grocery base. For the operational reception of the evacuated population, commissions were created from representatives of party and Soviet bodies. Great attention was paid to the rational placement of evacuees, taking into account the needs of the national economy of the republics and the labor force. Most of the evacuees were located in rural areas.

For the operational mission of the evacuated population, commissions were created from representatives of party and Soviet bodies. Great attention was paid to the rational placement of evacuees, taking into account the needs of the national economy of the republics and the labor force. Most of the evacuees were located in rural areas.

In the Latvian State Archives (LSU) and the Central State Archives of the Republic of Uzbekistan (CSA RUz) archival materials indicated the evacuation processes of the Baltic peoples.
According to the archival materials, in June 1941, people began to be evacuated from Central and Eastern European countries. Archival reports shows that, the first days of the WW II, the Council of People's Commissars of the Latvian SSR adopted resolutions on the organization of a mutual aid fund for evacuees to the population in 1941. The documents have statements that people received money from 200 to 300 rubles[13, p.1-4.]. In October 1941, 92 Latvians and 2 Estonians were evacuated from the Baltic countries to Tashkent and end of Oktober to the Uzbekistan SSR arrived 216 Lithuanian, 152 Latvian and 6 Estonian [14, p. 121]. On the 15th October 1941, 1 Latvian and 1 Estonian were placed in Bukhara province, 52 Lithuanian, 39 Latvian and 3 Estonians to Kharezm. Statistical archive documents states that, from 4.08.1941 to 31.10.1941 to Denav and Sarasiya districts of Sukhandarya province 3 Latvian and Lithuanians located [15, p.38]. It was placed 216 Lithuanians, 152 Latvian and 6 Estonians in Fergana province [16, p. 41].

Great attention was paid to attracting all schoolaged children to school, creating the material and moral conditions for children. Due to the fact that evacuated children were constantly brought to the republic, the number of orphanages, schools, and libraries increased. This increased the requirements for personnel. The need for teachers and educators was met by evacuated specialists, women with pedagogical education, experience working with children and volunteers [17, s. 757-760]. For instance, in Tashkent there was organized special nursing home and special schools for Baltic descendants. For example, In Navai region (school №318) and Tashkent city (school №7) were organized special schools for Lithuanians [18, s.103].

The events of the Second World War led to an increase in the number of the Baltic Diaspora in Uzbekistan - now there were 1,200 Latvians [19, s.145], there are no exact statistics available for Lithuanians and Estonians, but according to the static data of the Soviet Union, 950 Latvians, 953 Lithuanians and 658 Estonians registered in Uzbekistan in 1959.

Part 2: The role of the Baltic people in the socio-economic life of Uzbekistan

A. The Tashkent earthquake in 1966 and the role of Baltic people in its restoration

Exactly, 50 years ago, on April 26, 1966, at 5:23 am local time, a devastating earthquake occurred in Tashkent leaving homeless more than 300 thousand people out of 1.5 million of Tashkent residents. The capital was completely reconstructed over three and a half years. Entire residential areas have been erected in the suburbs of the city. After tragic earthquakes consequences, 75818 families in the Tashkent 


\begin{tabular}{|c|c|c|c|c|c|c|}
\hline \multirow{4}{*}{ Impact Factor: } & ISRA (India) & $=3.117$ & SIS (USA) & $=0.912$ & ICV (Poland) & $=6.630$ \\
\hline & ISI (Dubai, UAE & $=0.829$ & РИНЦ (Russia & $=0.156$ & PIF (India) & $=1.940$ \\
\hline & GIF (Australia) & $=0.564$ & ESJI (KZ) & $=\mathbf{5 . 0 1 5}$ & IBI (India) & $=4.260$ \\
\hline & JIF & $=1.500$ & SJIF (Morocco & $=5.667$ & OAJI (USA) & $=0.350$ \\
\hline
\end{tabular}

suffered from homelessness. As other Soviet Union nations, the Baltic nations played crucial role at the restoration Tashkent.

At a time when the Baltic countries sent aid to Tashkent, the first secretary of the Central Committee of the Latvian SSR, Augustus Eduardovich Voss, the chairman of the Central Committee of the Lithuanian SSR, A.Snechkus, the chairman of the Central Committee of the Estonian SSR, Alexey Muririsp, were responsible.

The press noted that it is an honor to help the people of Tashkent to the Baltic people and they did not forget Uzbekistan, which provided fraternal assistance to the Baltic people during World War II [20, 5.05.1972; 9.5.1969; №8].

On May 21, 1966, the Central Committee of the Communist Party of the Latvian SSR adopted resolution No. 279 on "On rendering emergency assistance to the city of Tashkent in the Uzbek SSR to eliminate the consequence of the earthquake".
According to the decree, the "Help Train of Latvia" was organized by 223 workers and the train arrived in Tashkent in June [21, 15.10.1977. №20].

According to the documents, a meeting of ministers of the USSR on the restoration of the city of Tashkent was held in the Uzbek SSR in May 1966. The meeting was attended by the chairman of the Gosstroy of the Latvian SSR Ya.F. Rubins and the deputy minister of construction of the Latvian SSR Ojārs Kārkliṇš. At the Council it was appointed that the Latvian SSR should build a total of 7.5 thousand square meters of living space and 2.5 thousand square meters of living space should have been built in 1966[22, p.1.]. Baltic workers won several awards at construction competitions among national champions of the country and fulfilled the plan of more than 23,900 square meters of living space [23, №20.]. According to the table 1 it can be seen them in detail:

Table 1. [24, p.27.].

\begin{tabular}{|l|l|c|l|l|l|l|c|}
\hline № & Republics & $\begin{array}{l}\text { living space } \\
\text { (by square } \\
\text { meters) }\end{array}$ & Roads & $\begin{array}{l}\text { Irrigation } \\
\text { system }\end{array}$ & Kindergarten & landscaping & Total \\
\hline 1 & $\begin{array}{l}\text { Lithuanian } \\
\text { SSR }\end{array}$ & 10,000 & 2 & 12 & 1 & 16 & 1 \\
\hline 2 & Latvian SSR & 8,900 & 22 & 10 & 1 & 13 & 6 \\
\hline 3 & Estonian SSR & 5,000 & 14 & 6 & 1 & 8 & 9 \\
\hline$\quad$ & Total & $\mathbf{2 3 , 9 0 0}$ & $\mathbf{8}$ & $\mathbf{2 8}$ & $\mathbf{3}$ & $\mathbf{3 7}$ & $\mathbf{2 6}$ \\
\hline
\end{tabular}

During restoration the Tashkent city 43 Latvian workers were awarded the diploma of the government of the Uzbek SSR, and 216 workers were awarded the "Tashkent Builder" sign. As well as Eduard Raubiško (Chief Engineer of the Train), Nikolay Didenko, Eduardo Stepanovs were awarded by the Order of the Red Banner of Labour[25, №20].
It should be noted that the contribution of the Lithuanians such as Kudryavtsev Fyodor (head of department), painter YankunasAlfredas, the driver Dizanov Dmitry, the chief engineer Jurgelenis Jonas, as well as painter from Estonia Vilast Malle, builder Begishev Enver, Beletsky Dmitry, stonemason Rayer Voldemar and Palmitz Michael.

Table 2. The statistical data of Baltic nations in Uzbekistan

\begin{tabular}{|c|c|c|c|c|c|c|}
\hline Nationality & 1926 & 1939 & 1959 & 1970 & 1979 & 1989 \\
\hline Lithuans & 317 & 334 & 953 & 1400 & 1040 & 1628 \\
\hline Latvian & 735 & 946 & 950 & 1199 & 1464 & 1131 \\
\hline Estonian & 216 & 1779 & 658 & 827 & 1064 & 854 \\
\hline Overal & 1268 & 2224 & 2563 & 3426 & 3544 & 3613 \\
\hline Nationality & \multicolumn{2}{|c|}{2000} & \multicolumn{2}{|c|}{2014} & \multicolumn{2}{|c|}{2017} \\
\hline Lithuans & \multicolumn{2}{|c|}{519} & \multicolumn{2}{|c|}{1093} & \multicolumn{2}{|c|}{1082} \\
\hline Latvian & \multirow{2}{*}{\multicolumn{2}{|c|}{140}} & \multicolumn{2}{|c|}{217} & \multicolumn{2}{|c|}{211} \\
\hline Estonian & & & & & & \\
\hline Overal & \multicolumn{2}{|c|}{1001} & \multicolumn{2}{|c|}{1859} & \multicolumn{2}{|c|}{$\begin{array}{l}538 \\
1831\end{array}$} \\
\hline
\end{tabular}




\begin{tabular}{|c|c|c|c|c|c|c|}
\hline \multirow{4}{*}{ Impact Factor: } & ISRA (India) & $=3.117$ & SIS (USA) & $=0.912$ & ICV (Poland) & $=6.630$ \\
\hline & ISI (Dubai, UAE & $=0.829$ & РИНЦ (Russia & $=0.156$ & PIF (India) & $=1.940$ \\
\hline & GIF (Australia) & $=0.564$ & ESJI (KZ) & $=5.015$ & IBI (India) & $=4.260$ \\
\hline & JIF & $=1.500$ & SJIF (Moroccc & $=5.667$ & OAJI (USA) & $=0.350$ \\
\hline
\end{tabular}

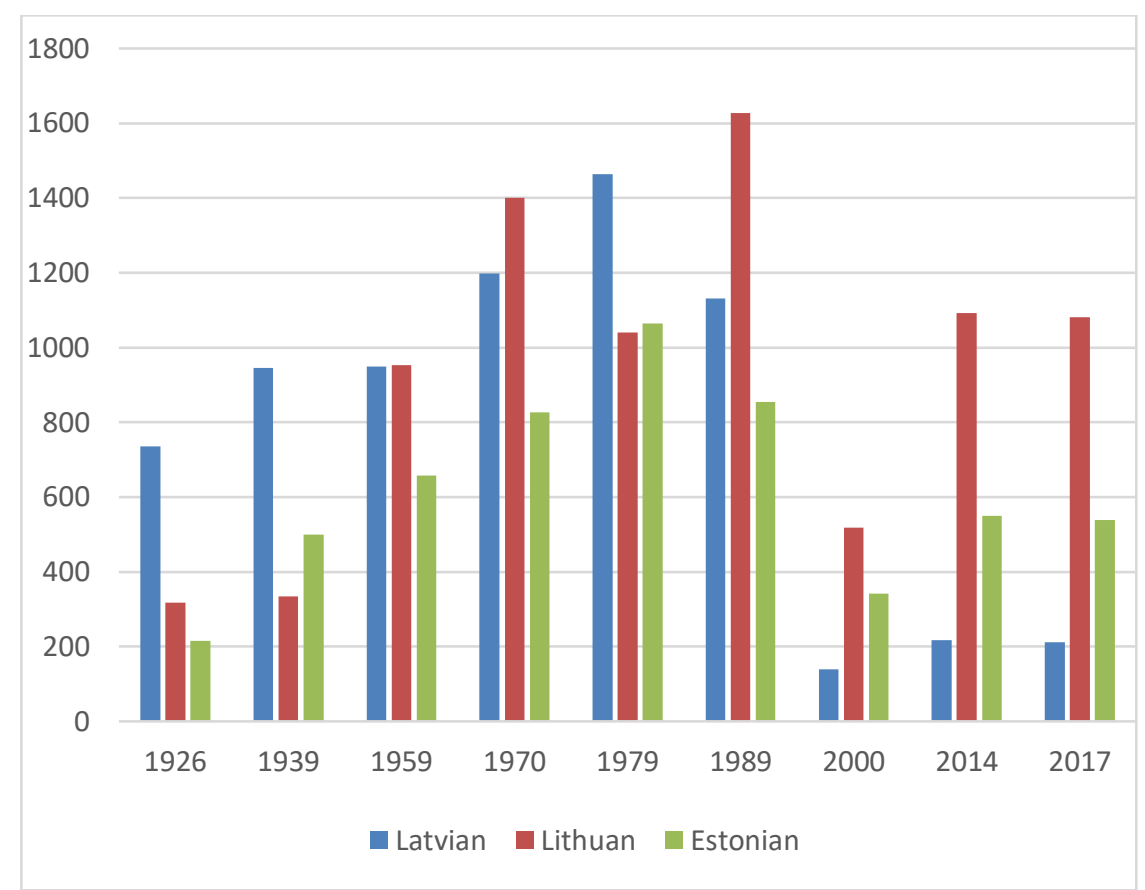

Picture 1. [26, CSC, demoscope.ru].

The bar chart shows that the nationalities of Latvians and Lithuanians have always been relatively high compared with the Estonian nation.

It can be seen that from 1941 to 1980 the rate of the Baltic people Diaspora in Uzbekistan reached the higher level due to the Second World War and the Tashkent earthquake (1966) developments. This is due to the fact that most of them at that time remained to live in Tashkent. After the collapse of the USSR, the process of returning to Russia or to their homeland became a mass phenomenon, and many Baltic peoples also migrated mainly to Russia, the USA and the Baltic states according to their nationality. As a result of these processes, the amount of the Baltic diaspora in Uzbekistan has been instilled in a reduction.

\section{Conclusion}

In in the mid-60s of the XIX centure, Baltic people migrated to Turkestan as a military and forced immigrant. In connection with the events of October 1917, they actively participated in the political process of establishing Soviet power in Turkestan.

Furthermore, Baltic nation diaspora contributes to the achievement of agricultural, irrigation, medicine, technical and other fields in Uzbekistan.Without forgetting the tolerance of Uzbek people's Baltic nations assisted to overcome consequences earthquake in Tashkent which happened in 1966 and a lot of them stayed in Tashkent. The Baltic Diaspora in Uzbekistan mostly live in the cities of Tashkent, Samarkand and Bukhara and communicates mainly in Russian. It is important that due to the development of partnerships and a policy of tolerance between Uzbekistan and the Baltic countries, it can be observed an increasing the number of Uzbek migrants coming to Baltic states in order to attend universities and tourism.

\section{References:}

1. 1.Khomitov, R. (2015). Uzbekiston Respublikasi va Latviya, Litva, Estoniya urtasidagi aloķalar yangi bosķichda (19912014). (pp.9-10). Tashkent.

2. Khomitov, R. (2015). Relations between Uzbekistan and Latvia, Lithuania and Estonia at a new stage (1991-2014). (pp.9-10). Tashkent. Turon zamin ziyo.

3. Polovnikova, N. A. (1997). Torgovie Puti Pribaltiyskogo yantarya $v$ Sredney Azii (drevnost, srednevekove). Goroda $i$ caravansarai na trassax Velikogo Shelkovogo puti. 


\begin{tabular}{|c|c|c|c|c|c|c|}
\hline \multirow{4}{*}{ Impact Factor: } & ISRA (India) & $=3.117$ & SIS (USA) & $=0.912$ & ICV (Poland) & $=6.630$ \\
\hline & ISI (Dubai, UAE & $=0.829$ & РИНЦ (Russia & $=0.156$ & PIF (India) & $=1.940$ \\
\hline & GIF (Australia) & $=0.564$ & ESJI (KZ) & $=\mathbf{5 . 0 1 5}$ & IBI (India) & $=4.260$ \\
\hline & JIF & $=1.500$ & SJIF (Morocco & $=5.667$ & OAJI (USA) & $=0.350$ \\
\hline
\end{tabular}

Thesis on the workshop Yunesko. (pp.27-28). Urgench.

4. Gornukhova, M. V. (2004). Migracionnie processi $v$ respublikah Pribaltiki $v X X$ veke. diss...kand.econom. nauk. (pp.45-47). Moscow.

5. Khomitov, R. (2015). Relations between Uzbekistan and Latvia, Lithuania and Estonia at a new stage (1991-2014). (p.99). Tashkent. Turon zamin ziyo.

6. Khomitov, R. (1897). Relations between Uzbekistan and Latvia, Lithuania and Estonia at a new stage (1991-2014); Itogi perepis' naseleniya 1897 goda.

7. (n.d.). LatvijasValstsvēsturesarhīvs (Latvian State Historical Archive). Fund. 235, inventory6, case -598 , p. 12.

8. Matveev, A. I. (1977). Zarubezhnye vykhodtsy v Turkestane na puti $k$ Velikomu Oktyabryu. (pp.95-108). Tashkent.

9. (2002). Etnicheskiy atlas Uzbekistana. Institut "Otkrytoe Obshchestvo" -Fond sodeystviya. (p.149). Uzbekistan.

10. Inoyatov, Kh. (1986). Uzbekistonda oktyabr revolyutsiyasi galabasi. (p.99). Tashkent.

11. (n.d.). Central State Archive of Republic of Uzbekistan, fund-1318, inventor -1, case-2, p.2.

12. (2002). Etnicheskiy atlas Uzbekistana. Institut "Otkrytoe Obshchestvo" - Fond sodeystviya Uzbekistan.

13. (1914). Turkestanskie vedomost'i. №77.

14. Vert, A. (1964). Rossiya v voyne 1941-1945. Retrieved 2019, from http://oldru.com/rus_41_45/12.htm
15. (n.d.). Latvian State Archive, Fund-270, inventor -1, case- 77, pp.1-4.

16. (n.d.). Central State Archive of the Republic of Uzbekistan, Fund - R-314, inventor -1, case 361, p.121.

17. (n.d.). Central State Archive of the Republic of Uzbekistan. Fund-314, inventory-1, case-60, p.38.

18. (n.d.). Central State Archive of the Republic of Uzbekistan. Fund-314, inventory-1, case-60, p.41.

19. Saidova, G. Sh. (2013). Zhizn' evakuirovannykh detey v Uzbekistane v gody Vtoroy mirovoy voyny. Molodoy uchenyy, №12, 757-760.

20. Khomitov, R. (2015). Uzbekiston Respublikasi va Latviya, Litva, Estoniya y̆rtasidagi aloķalar yangi bosķichda (1991-2014). (pp.9-10, p.103). Tashkent.

21. (2002). Etnicheskiy atlas Uzbekistana. Institut "Otkrytoe Obshchestvo" - Fond sodeystviya. (p.145). Uzbekistan.

22. (n.d.). Komsomol Uzbekistana, 5.05.1972; Pravda Vostoka, 9.5.1969; Ekonomika i zhizn', 1972, №8.

23. (1977). Zvaigzne, 15.10.1977. №20.

24. (n.d.). Latvian State Archive, fund-270, inventory-1, case -3037 , p.1.

25. (n.d.). For 1926, 1939, 1959, 1970, 1979, 1989 years information taken from the www.demoscope.ru/weekly/ssp/sng_nac_39.ph p For 2000, 2014, 2017years information taken from the Statistical Committee of the Republic of Uzbekistan. 